Jurnal Sains Riset (JSR)

p-ISSN 2088-0952, e-ISSN 2714-531X

http://journal.unigha.ac.id/index.php/JSR

DOI. $10.47647 /$ jsr.v10i12

\title{
THE MANAGEMENT OF SPEAKING INSTRUCTION AT SMA MODAL BANGSA, ACEH PROVICE
}

\author{
Sariakin \\ Program Studi Bahasa Inggris, STKIP Bina Bangsa Getsempena \\ Email : Sariakin70@gmail.com
}

\begin{abstract}
The purposes of this research are (1) to find out how the teachers make preparation for managing speaking instruction, (2) to find out how English teachers design classroom management for teaching speaking skill, and (3) to find out how the teachers make as assessment of speaking instruction. The subject of this research is all teachers of SMA Modal Bangsa who teach English especially speaking skill and there are four subjects. The design used in this research is descriptive research and it belongs to qualitative research. Thus, this research is conducted to analyze a management of speaking instruction at the school. Data needed were gotten through observation, interview, and documentation. Data gotten are analyzed by narration procedure and discussing. The result of the research shows that the teachers prepare classroom management of reading instruction by preparing lesson plan, materials, and conducive environment for instruction process. Next, the teachers usually use six methods namely: asking opinion, debate, roll play, discussion, problem solving and speech in managing speaking instruction. Furthermore, the teachers evaluate the students in teaching English speaking skill in two kinds of tests namely on going process test and final test. The tests of English speaking skill were orally. The tests are parted into six categories, there are: fluency of speaking, pronunciation, grammar, sound gesture and content
\end{abstract}

Key Word: Management, Speaking, Instruction

\section{Introduction}

Every one should master English because it is as a language. Since it is as an language, thus it must be taught at schools from secondary schools till higher schools or university even it is taught at kindergartens now days. There are four language skills in English; speaking, listening, reading, and speaking that must be taught at schools. However teachers usually face various problems in teaching English at schools especially in teaching speaking. Besides, they face different problems in various situations in teaching speaking.

Regarding this research, SMA Negeri Modal Bangsa which was research participant recorded the quality of teaching learning process of English especially speaking in the school showed satisfactory performance. Further, general students of the school always meet required standard in mastering English especially in speaking skill. Based on the fact, the researcher makes an investigation to figure out on what may cause the success, and then the writer assumes that the management of teaching learning 
Jurnal Sains Riset (JSR)

p-ISSN 2088-0952, e-ISSN 2714-531X

http://journal.unigha.ac.id/index.php/JSR

DOI. $10.47647 /$ jsr.v10i12

process of speaking skill can take part of the success.

As a matter of fact, teacher plays a vital rule in teaching and learning process. Brown (2001) mentions an instruction or teaching and learning process which has purposed at organizing learning and learning activities. There are many ways to increase students' proficiency in speaking such as managing classroom instruction and encouraging student's interest to speak in class. This will be applying through creating English sentences on classroom, English-written picture posters, English written magazines, etc. They will be inspired because classroom as an opportunity for learning and language practicing.

$$
\text { Applying a proper }
$$
management is a classroom that provide as many as possible opportunities for students to use English and to enjoy learning it.

This research is intended to analyze the rule of management in teaching speaking or teaching learning process of speaking. Next, the research would cover management for teaching learning process of speaking at SMA Negeri Modal Bangsa.

The school is chosen as the location of this research because of some factors and of them is that students' speaking ability of the school is good. One of causes that makes the students' speaking ability good is management of class room instruction applied by teacher is good. Consequently, it can motivate the students in learning speaking. Therefore, it is necessary to investigate the management of speaking class or teaching learning process of speaking at the school.

\section{Research Method}

\section{a. Research Design}

This research is conducted at SMA Negeri Modal Bangsa. The design used in this research is descriptive research. The descriptive research is used to analyze the management of speaking instruction which is applied at SMA Negeri Modal Bangsa. Therefore, this research belongs to qualitative research because only describes and analyze the management of speaking instruction at the school.

\section{b. Subject of Research}

Subject is the whole number of people and inhabitants occupying a specific geographical locality or it is the total number or amount of things, especially within a given area or it is a part (as in population) used for purpose of investigating and comparing properties. Next, the subject of this research is four English teachers who teach English at the school and they are as data source of this research.

\section{c. The Instruments of Collecting Data}

The instruments are used by the researcher for collecting data are observation sheet, interview, and documentation. The data are collected by observing management for teaching and learning process, interviewing the teachers, and analyzing documents.

\section{d. Data Analysis}

The data gotten are analyzed by organizing the collected data systematically. The data are grouped and classified based on the research problems. The data are qualitatively analyzed by the researcher to identify, and recognize the verbal instructions and then, group them according to the topic. Next, the 
Jurnal Sains Riset (JSR)

p-ISSN 2088-0952, e-ISSN 2714-531X

http:/ /journal.unigha.ac.id/index.php/JSR

DOI. $10.47647 /$ jsr.v10i12

data gotten are analyzed through narrating and discussing.

\section{Research Result}

In preparing classroom
management for speaking
instruction, the teachers prepared
lessons plan, materials, and condition of environment which was comfortable. Next, in managing teaching and learning process, the teachers usually use group the students into some groups. Every group consists of four till five students. Next, the students are given a topic to be discussed. Besides, the teachers usually use pictures in teaching speaking. Next, the students are asked to tell or describe the picture orally one by one. Sometimes, the teachers ask them to have conversation in front of class in a pair.

Next, the teachers have to speak English in teaching and learning process. The students are more early able to speak English well because they follow and imitate the teachers when the teachers speak English in the class room and the students usually communicate with English teacher by English in the class. Furthermore, the teachers usually use LCD, TV, and tape recorder in managing speaking instruction.

After teaching and learning process, the teachers conduct an evaluation to know the success of managing teaching and learning process and the students' achievement in mastering the subject that had been discussed. The teachers evaluate the students by two kinds of evaluation, namely daily evaluation or on going process evaluation and final evaluation. The evaluation is done by the teacher orally. There are six categories that is evaluated the students by the teacher: (1) fluency of peaking, pronunciation, (3) grammar, (4) sound, (5) gesture, and (6) content. Next, the management of teaching and learning process of speaking skill that is conducted by teacher has a good impact on the students' ability in mastering speaking skill.

\section{Discussions}

The teachers prepare management for speaking instruction by preparing syllabus and lesson plan, materials, and the condition of classroom for instruction.

The teachers prepare lesson plan based on the syllabus that is published by government. The lesson consists of materials that will be taught by the teachers. In teaching materials, the teachers also prepare technique or method that will be used in teaching and learning process.

Next, materials that will be
taught should be very
comprehensive. The materials go into the specific situations of learning and hence, their development should take into account, their terminal behaviors. Proper care is to be taken to ensure that learning activities are developed and presented in suitable sequences, facilitating effective learning. Logical continuity can be attained by proper sequencing of the learning experiences. Thereby, the fifth step in the development of an instructional system, is the preparation of learning material. Besides, the teachers must create a conducive environment in conducting teaching and learning process in order that the students can 
Jurnal Sains Riset (JSR)

p-ISSN 2088-0952, e-ISSN 2714-531X

http:/ /journal.unigha.ac.id/index.php/JSR

DOI. $10.47647 /$ jsr.v10i12

follow teaching and learning process comfortably.

The English teachers do not develop the instructional activities based on their lesson plans because they prepare the lesson plans only to be beneficial for fulfilling in the regulating system requirement in case inspectors and school principles step down to look at the syllabus and lesson plan.

In managing the instruction of speaking skill, the teachers usually group the students to be some groups. Sometimes they use pictures in teaching learning process of speaking skill. The teachers usually ask the students to discuss the given topic and ask them have conversation in front of class. Next, the teacher familiarizes students to pronounce words correctly. And then, the teachers guide students to communicate by using good grammar. The teachers usually use felicities such as tape recorder, television, in focus, and LCD in managing speaking classroom

The teachers usually give the students oral test continually for monitoring students' progress in speaking skill. The teacher requires students to communicate in English during the teaching learning process of English especially speaking skill so that students can memorize the vocabulary and add their vocabulary.

In addition, the management of teaching and learning process of speaking skill that is conducted by teachers has a good impact on the students' ability in mastering speaking skill.

Finally, the theory of management of instruction process by Smith and Lastett (2011) can still be used to overcome the problems of instruction process. Besides, the theory can still be used to solve the problems in instruction process of speaking skill.

\section{Conclusions and Suggestions \\ a. Conclusions}

The English teachers of SMA Modal Bangsa prepare management of speaking instruction by preparing lesson plan before teaching include of the program of year, the program of semester, the effective week, the syllabus, and the teaching plan.

The teachers usually use six methods in managing teaching speaking skill namely: asking opinion, debate, roll play, discussion, problem solving and speech.

The teachers evaluate students in teaching English especially speaking skill in two kinds of tests namely on going process test and final test. The tests of English speaking skill is conducted orally. The tests are parted into six categories, there are: fluency of speaking, pronunciation, grammar, sound gesture and content. There were four factors that made the students were able to speak English well: Good teachers, good students, good environment and enough facilities.

The management of teaching and learning process of speaking skill that is conducted by teacher has a good impact on the students' ability in mastering speaking skill.

\section{b. Suggestion}

It is realized that this research is not perfect, thus the other researchers are suggested to conduct a research that still relates to this research by using the other designs such as a classroom action research or an experimental research or 
Jurnal Sains Riset (JSR)

p-ISSN 2088-0952, e-ISSN 2714-531X

http://journal.unigha.ac.id/index.php/JSR

DOI. $10.47647 /$ jsr.v10i12

enlarging the location of research such as Junior High School or university level.

\section{Bibliography}

Brown \& G. Yule. 2003. Teaching the Spoken Language. New York: Cambridge University Press.

Brown, H., D. 2001. Teaching by Principal: An Interactive Approach to Language Pedagogy. New York: Longman Group Limited.

Colin., S. \& Robert., L. Effective Classroom Management. (on line) http/www. Microsoft reader book. Com. Accessed on February 1, 2011.

Hombay. 1999. Instructional Models in Class Design. New York: Longman Group
Limited.

Larsen, D. 2000. Technique and Principle in Language Learning Teaching, New York: Oxford University Press.

Leaser. 2006. Instruction and Instructional System. California. Good Year Company.

Moleong, L.,J. 2017. Metodologi Penelitian Kualitatif. Bandung: PT. Remaja Rosdakarya Offset

Savignon. 2003. Teaching Speaking as Foreign Language. Boston: Language Inc.

Slavin. 2002. Cooperative Learning in Teaching English as Second Language. New York: Oxford University Press. 